\title{
Screening of sustainable groundwater sources for integration into a regional drought-prone water supply system
}

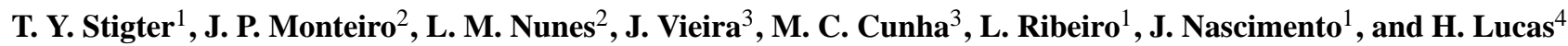 \\ ${ }^{1}$ Geo-Systems Centre/CVRM, Instituto Superior Técnico, Lisbon, Portugal \\ ${ }^{2}$ Geo-Systems Centre/CVRM, Universidade do Algarve, Faro, Portugal \\ ${ }^{3}$ FCTUC - Departamento de Engenharia Civil, Coimbra, Portugal \\ ${ }^{4}$ Águas do Algarve, Faro, Portugal
}

Received: 16 October 2008 - Published in Hydrol. Earth Syst. Sci. Discuss.: 6 January 2009

Revised: 31 March 2009 - Accepted: 29 June 2009 - Published: 15 July 2009

\begin{abstract}
This paper reports on the qualitative and quantitative screening of groundwater sources for integration into the public water supply system of the Algarve, Portugal. The results are employed in a decision support system currently under development for an integrated water resources management scheme in the region. Such a scheme is crucial for several reasons, including the extreme seasonal and annual variations in rainfall, the effect of climate change on more frequent and long-lasting droughts, the continuously increasing water demand and the high risk of a single-source water supply policy. The latter was revealed during the severe drought of 2004 and 2005, when surface reservoirs were depleted and the regional water demand could not be met, despite the drilling of emergency wells.

For screening and selection, quantitative criteria are based on aquifer properties and well yields, whereas qualitative criteria are defined by water quality indices. These reflect the well's degree of violation of drinking water standards for different sets of variables, including toxicity parameters, nitrate and chloride, iron and manganese and microbiological parameters. Results indicate the current availability of at least $11001 \mathrm{~s}^{-1}$ of high quality groundwater $(55 \%$ of the regional demand), requiring only disinfection $\left(9001 \mathrm{~s}^{-1}\right)$ or basic treatment, prior to human consumption. These groundwater withdrawals are sustainable when compared to mean annual recharge, considering that at least $40 \%$ is preserved for ecological demands. A more accurate and comprehensive analysis of sustainability is performed with the help of steady-state and transient groundwater flow simulations, which account for aquifer geometry, boundary conditions, recharge and discharge rates, pumping activity and season-
\end{abstract}

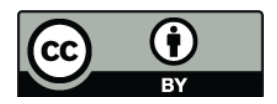

Correspondence to: T. Y. Stigter (tibor.stigter@ist.utl.pt) ality. They permit an advanced analysis of present and future scenarios and show that increasing water demands and decreasing rainfall will make the water supply system extremely vulnerable, with a high risk of groundwater salinization and ecosystem degradation.

\section{Introduction}

\subsection{The need of integrated water resources management}

The concept of integrated water resources management (IWRM) has gained importance worldwide, and the need to deal with its complexity has led to the increased use of decision support tools. Several articles dealing with such tools have been published, e.g. for integrated river basin management to simulate the economic impacts of policies in drought periods (Characklis et al., 1999; Booker et al., 2005), to quantify the economic value of stream flow (PulidoVelazquez et al., 2006, 2008), for policy options and water allocation (Letcher et al., 2004), for trade-offs between competing uses (Burke et al., 2004), for analysis of the impact of climatic changes (Tanaka et al., 2006), and for trade-offs between efficiency, equity and sustainability in the design of water programs (Ward and Pulido-Velazquez, 2008).

IWRM drives individual sectors to coordinate actions and collaborate with each other and enhances stakeholder participation, transparency and cost effective local management (Mylopoulos and Kolokytha, 2008). The objectives of IWRM for socio-economic development and sustainable development require the adoption of three key policy principles (Postel, 1992): i) equity, i.e., water is a basic need and no human can live without a minimum amount and quality;

Published by Copernicus Publications on behalf of the European Geosciences Union. 
ii) ecological integrity, i.e., water resources are only sustainable if the environment is capable of regenerating water of sufficient quality and quantity; iii) economic efficiency, i.e., water is a scarce resource, though not necessarily an ordinary economic good (Savenije, 2002), therefore must be used efficiently.

In the Algarve region, south Portugal, there are a number of factors that impose the need for an IWRM scheme. First of all, in semi-arid regions such as the Algarve, the seasonal and annual variations in rainfall are extreme, posing serious challenges for water supply planning and management. Second, the intensity and frequency of occurrence of extreme droughts will most likely increase significantly in the future, according to the climate change study for Portugal (Santos and Miranda, 2006). Climate models predict a 10 to $40 \%$ lowering of rainfall in the south of Portugal by the end of this century. In general, climate change will be pronounced in the Mediterranean region, due to the magnitude of expected changes in temperature and rainfall patterns (Giorgi, 2006). Moreover, water resources are arguably the most important domain to be considered in studies that assess the impact of climate change (Cunha et al., 2006). This importance stems from the fact that climate change has direct impacts on the availability, timing and variability of water supply and demand, and is also related to the significant consequences of these impacts on many sectors of our society.

Third, the water demand in the region is continuously increasing, owing to the growth of population and tourism. Agriculture is still by far the major water-consuming activity. Annual water consumption in the Algarve is currently estimated to be around $280 \mathrm{hm}^{3}\left(\times 10^{6} \mathrm{~m}^{3}\right)$, of which $69 \%$ is for agriculture, $23 \%$ for public supply and $8 \%$ for other activities (golf courses, industry, private wells). Though groundwater is the main source for irrigation $\left(165 \mathrm{hm}^{3}\right)$, irrigation with surface water is gaining importance.

Fourth, a water supply policy based on a single source significantly increases the risk of failing to meet water demand, either during long drought spells or due to accidental events. Such failure occurred in the Algarve during the severe drought of 2004 and 2005, when stored water volumes in surface reservoirs dropped dramatically, reaching the exploitation limit in the west. Currently, an additional dam (Odelouca) is being built, which will be completed in 2010, but studies have shown that even then water demand will be hard to meet in the long term (Hidroprojecto and Ambio, 2005).

\subsection{Objectives of the study}

For all the above-stated reasons an IWRM scheme for public water supply is essential to guarantee a stable and sustainable public water supply, obtaining a correct balance between the various water resources. Under an IWRM scheme, naturally, groundwater will be a valuable resource for public supply. Before the existence of the multi-municipal pub- lic water supply system (MPWSS), public water supply was mainly supported by groundwater. Moreover, several studies have pointed out the advantage of the joint use of surface and groundwater for treatment requirements (e.g. Campinas et al., 2001). Since well yield and water quality vary significantly over space and time, one of the necessary tasks of the OPTEXPLOR project, a R\&D project financed by the Algarve Water Utility with the aim to create a decision support system based on an optimization model, was the quantitative and qualitative screening and selection of public groundwater wells for integration into the MPWSS. Only the best wells should be used for public supply and included in an integrated management scheme of the water resources. This paper aims to present the methodology and the results of the selection made, as well to analyze the sustainability of groundwater withdrawals from the screened wells. This latter analysis is essential as overexploitation can lead to degradation of the aquifer (e.g. due to seawater intrusion) and desiccation of associated wetlands. There are no general rules to define sustainable yields, because they depend on regional factors such as climate (and climate change), the hydrogeological setting, the particular location of the wells, the presence of groundwater dependent ecosystems, as well as social, economic and legal aspects (Sophocleous, 2000; Custodio, 2002; Alley and Leake, 2004; Maimone, 2004; Seward et al., 2006; Ponce, 2007). Therefore, regional groundwater flow models are used to simulate the response of the aquifers to different rates of groundwater pumping. In this paper, results of flow simulations are presented for the largest and most productive system of the Algarve (Querença-Silves aquifer) to illustrate the analysis of groundwater resources sustainability at the regional level.

\section{Study area}

\subsection{Climate}

The Algarve region $\left(5400 \mathrm{~km}^{2}\right)$ is the southernmost province of Portugal, as indicated in Fig. 1. The region is characterized by a warm Mediterranean climate. A mean annual precipitation of $653 \mathrm{~mm}$ was calculated for the period 1941/42-1973/74 (Loureiro and Nunes, 1980). The precipitation regime is irregular, having intermittent periods with short and sharp floods in the winter and a long dry period in the summer. In addition, there may be extreme events such as inter-annual periods of drought.

\subsection{Hydrogeology}

The actual state of development of the Algarve hydrogeology allows the definition of 17 aquifer systems with regional importance, as proposed by Almeida et al. (2000); their location and geometry are shown in Fig. 1. The most productive aquifers are built up of karstified limestones and dolomites. 


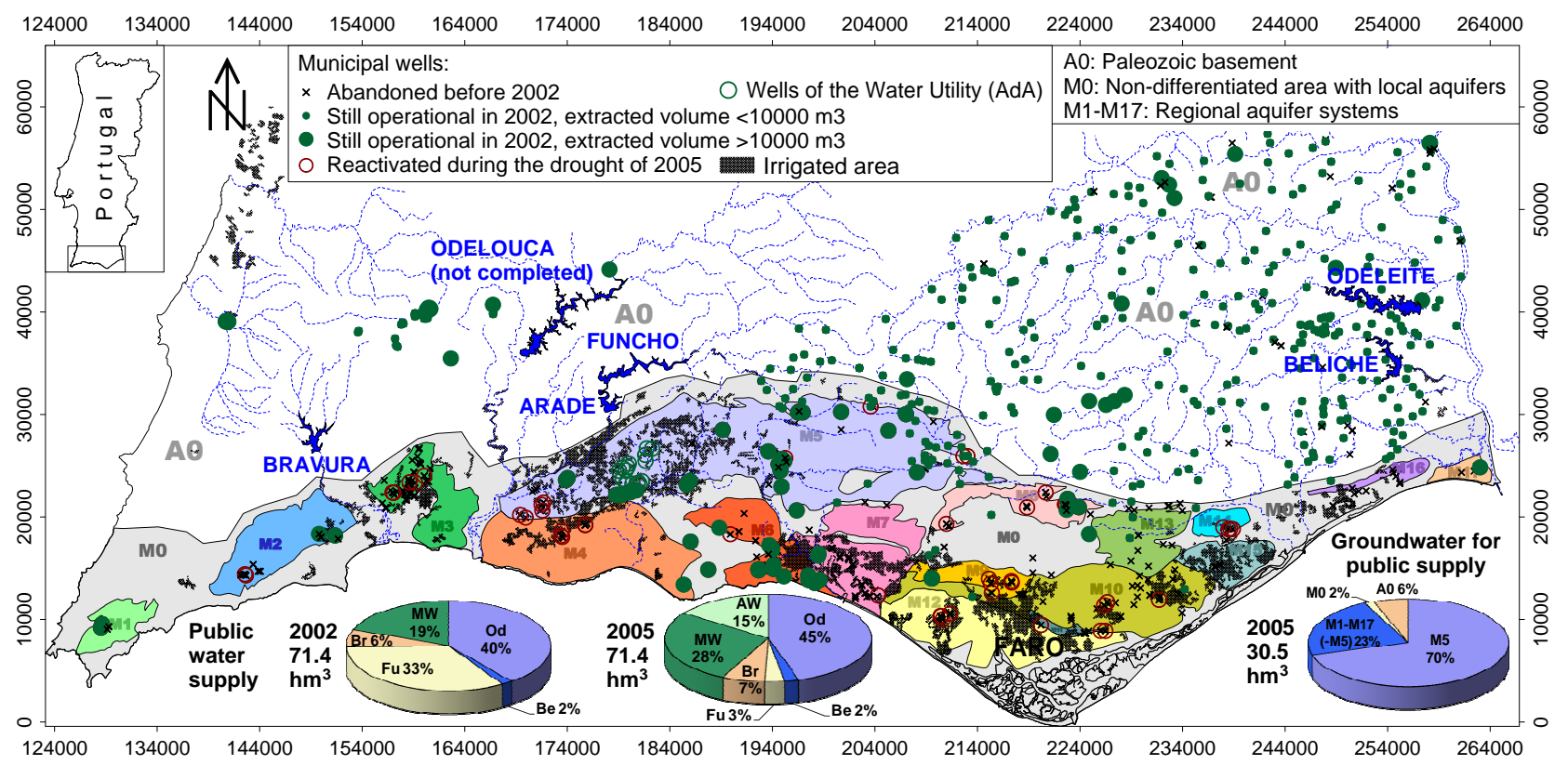

Fig. 1. Location of the municipal wells and aquifer systems with regional expression in the Algarve; also shown are the main rivers and surface reservoirs: $\mathrm{Od}=$ Odeleite, $\mathrm{Be}=$ Beliche, $\mathrm{Fu}=$ Funcho, $\mathrm{Br}=$ Bravura; groundwater wells: $\mathrm{AW}=\mathrm{AdA}$ Water Utility, $\mathrm{MW}=\mathrm{Municipal}$.

Table 1. Characterization of aquifer systems with regional expression in the Algarve.

\begin{tabular}{|c|c|c|c|c|c|c|}
\hline \multicolumn{2}{|c|}{ Aquifer system } & \multirow{2}{*}{$\begin{array}{l}\text { Main aquifer lithology } \\
\operatorname{lmst}^{b}, \mathrm{dlmt}^{\mathrm{c}}\end{array}$} & \multirow{2}{*}{$\begin{array}{r}\begin{array}{r}\text { Area } \\
\left(\mathrm{km}^{2}\right)\end{array} \\
22.56\end{array}$} & \multirow{2}{*}{$\begin{array}{r}\text { Mean } Q^{\mathrm{a}} \\
\left(1 \mathrm{~s}^{-1}\right) \\
15.5\end{array}$} & \multirow{2}{*}{$\begin{array}{r}\begin{array}{r}\text { Recharge } \\
\left(\mathrm{hm}^{3} \mathrm{yr}^{-1}\right)\end{array} \\
6.0\end{array}$} & \multirow{2}{*}{$\begin{array}{r}\text { Withdrawal } \begin{array}{r}2005 \\
\left(\mathrm{hm}^{3}\right)\end{array} \\
0.36\end{array}$} \\
\hline M1 & Covões & & & & & \\
\hline M2 & Almádena - Odeáxere & lmst, dlmt & 63.49 & 5.6 & 16.6 & 0.55 \\
\hline M3 & Mexilhoeira Grande - Portimão & lmst, dlmt, sand & 51.71 & 8.3 & 10.0 & 1.18 \\
\hline M4 & Ferragudo - Albufeira & lmst, sand & 117.1 & 5 & 10.0 & 0.40 \\
\hline M5 & Querença - Silves & lmst, dlmt & 317.85 & 11.1 & 93.4 & 21.44 \\
\hline M6 & Albufeira - Ribeira de Quarteira & lmst, dlmt & 54.55 & 9.4 & 10.0 & 0.55 \\
\hline M7 & Quarteira & lmst, dlmt, sand & 81.19 & 9 & 15.0 & 0.13 \\
\hline M8 & S. Brás de Alportel & lmst, dlmt & 34.42 & 4.2 & 5.5 & 0.34 \\
\hline M9 & Almansil - Medronhal & lmst, dlmt & 23.35 & 7 & 6.5 & 1.92 \\
\hline M10 & S. João da Venda - Quelfes & sand, lmst, marl & 113.31 & $7.0 ; 5.5$ & 9.0 & 0.49 \\
\hline M11 & Chão de Cevada - Qta. João de Ourém & lmst, dlmt & 5.34 & 6 & 2.0 & 0.51 \\
\hline M12 & Campina de Faro & lmst, sand & 86.39 & 6 & 8.3 & 0.13 \\
\hline M13 & Peral - Moncarapacho & lmst & 44.07 & 2.8 & 10.0 & 0 \\
\hline M14 & Malhão & $\operatorname{lmst}$, dlmt & 11.83 & 14.7 & 3.0 & 0.33 \\
\hline M15 & Luz - Tavira & lmst, sand & 27.72 & 5.6 & 4.8 & 0 \\
\hline M16 & S. Bartolomeu & lmst, dlmt & 10.6 & 8.2 & 3.0 & 0 \\
\hline M17 & Monte Gordo & sand & 9.62 & $1.5-3.0$ & 3.0 & 0 \\
\hline
\end{tabular}

a yield, ${ }^{b}$ limestone, ${ }^{\mathrm{c}}$ dolomite

Table 1 presents the main characteristics of each system, including dominant aquifer lithology, average yield and annual recharge. The six most important aquifers for public water supply are M2, M3 (northern sector), M5 (also significantly exploited for irrigation), M8, M9 and M14. Of the other aquifer systems, M7, M10 and M12 are particularly important groundwater suppliers for irrigation. Due to its large area and significant recharge, as well as the high degree of karstification, aquifer system M5, known as QuerençaSilves, constitutes the most important groundwater reservoir. Its geometry is pictured in Fig. 2. Built up of massive karstified limestones and dolomites, the system is bounded to 


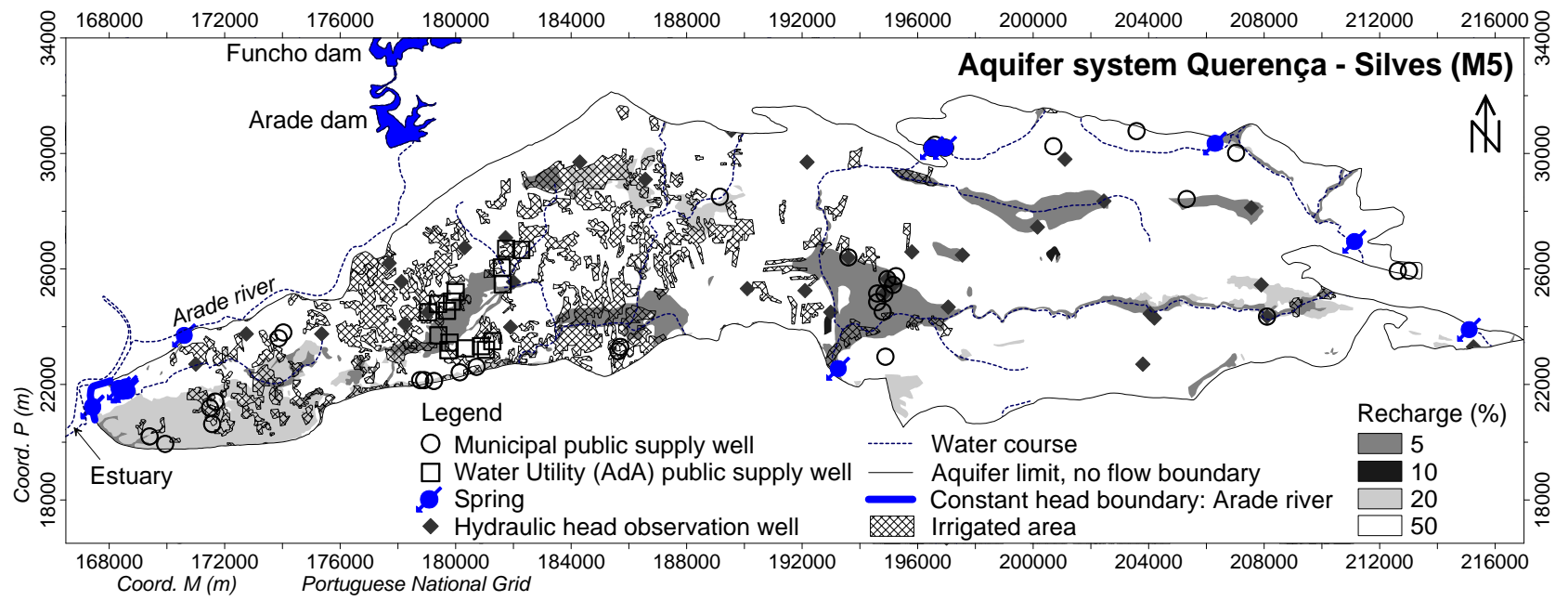

Fig. 2. Spatial distribution of recharge expressed as percentage of precipitation and boundary conditions of the Querena-Silves aquifer system. Also indicated are public supply wells, hydraulic head observation wells, springs and irrigated areas.

the north by clays, mudstone and evaporites and to the south by a large thrust-fault zone, forming groundwater flow barriers. Discharge occurs at the springs located along the aquifer boundary, predominantly in the west, near the Arade estuary (Fig. 2). Important and sensitive surface/groundwater ecotones and associated groundwater dependent ecosystems exist at the location of these springs, many of them classified as protected areas.

\subsection{Evolution of the use of groundwater through time}

Previous publications (Monteiro and Costa, 2004; Nunes et al., 2006a; Stigter et al., 2007) provide an overview of the evolution of surface and groundwater use in the Algarve. An exponential rise in water demand occurred in the 1960s, mainly associated to the expansion of irrigated agriculture and the growth of tourism. This was possible thanks to the introduction of drilling technologies that led to the construction of thousands of boreholes in the region, without adequate regional planning nor supported by existing knowledge of the region's hydrogeology.

Despite the construction of the Arade and Bravura dams, groundwater remained the dominant source for irrigation (using private wells) and public supply until the end of the 20th century. Public supply was locally and independently managed by each of the 16 municipalities (whose wells are located in Fig. 1), so that regional water supply planning, management and quality control was impossible. At the same time, a few aquifers were suffering increasing pressures from human activities, such as nitrate contamination in irrigated areas (Stigter et al., 1998, 2006a, b) and saltwater intrusion in coastal sectors (Carreira, 1991; Salgueiro and Ribeiro, 2001).

The efforts to abandon groundwater as a source for public supply started in 1998, after a large investment in new infras- tructures (Funcho and Odeleite dams, water treatment plants, regional distribution system) and in the rehabilitation of others (Beliche and Bravura dams). The abrupt policy change led to the implementation of a MPWSS entirely based on surface water supplied by the reservoirs and in 2002 more than $80 \%$ of the total public supply was sustained by surface water, as illustrated in Fig. 1. The major benefits of the use of surface water were felt in water quality control. The MPWSS does not supply water for irrigation of agricultural land; though several surface irrigation districts exist, irrigation continues to rely largely on groundwater.

The negative consequences of this single-source water supply policy were felt during the severe drought that occurred in 2004 and 2005, causing an overall $87 \%$ depletion of the surface water storage and the complete depletion of the Funcho and Arade reservoirs. Restrictions on water use were imposed for all economic sectors, but particularly agriculture, with exceptional measures being taken to avoid the total disruption of the public water system. The Regional Water Utility, Águas do Algarve, S.A. (AdA), decided to drill emergency wells in the Querença-Silves aquifer system (M5). Despite the additional $11 \mathrm{hm}^{3}$ supplied by this aquifer, the water demand could not be met by the MPWSS and formerly abandoned municipal wells had to be reactivated (for location see Fig. 1). In total $42 \%$ of the public water supply was supported by groundwater in 2005 . An overview of the distribution of groundwater supply among the main aquifer systems is shown in Fig. 1, revealing the dominant role of M5. 
Table 2. Definition of Standard Violation Indexes (SVIs) used in the present study.

\begin{tabular}{llrrrr}
\hline Standard Violation Index & Definition & $t_{0}-t_{u}$ & $\mathrm{NA}^{\mathrm{a}}$ & $\mathrm{NV}^{\mathrm{b}}$ & $\%_{V}$ \\
\hline $\mathrm{SVI}_{\mathrm{Tot}}$ & All parameters & $1995-2005$ & 38362 & 3939 & $10.3 \%$ \\
$\mathrm{SVI}_{\mathrm{Tox}}$ & Toxicity parameters & $1995-2005$ & 5670 & 15 & $0.3 \%$ \\
$\mathrm{SVI}_{\mathrm{Microb}}$ & Microbiological parameters & $1995-2005$ & 3040 & 1077 & $35.4 \%$ \\
$\mathrm{SVI}_{\mathrm{NO}_{3}, \mathrm{Cl}}$ & Nitrate and Chloride & $1995-2005$ & 5708 & 1029 & $18.0 \%$ \\
$\mathrm{SVI}_{\mathrm{Fe}, \mathrm{Mn}}$ & Iron and Manganese & $1995-2005$ & 4339 & 723 & $16.7 \%$ \\
\hline
\end{tabular}

${ }^{a}$ Number of analyses, ${ }^{b}$ Number of violations

\section{Well screening and selection}

\subsection{Methods}

The screening and selection of groundwater wells for integration into the MPWSS was based on quantitative and qualitative criteria. Regarding the former, the overall characteristics of the regional aquifer systems in the Algarve were studied based on published reports (e.g. Silva, 1984; Silva, 1988; Almeida et al., 2000) and well yields were analyzed individually when available. A well yield criterion of $151 \mathrm{~s}^{-1}$ was defined, based on field experience and expertise and met by three-quarters of the wells with known yields. Some wells with lower yield were included, depending on their location and on the aquifer properties.

The qualitative screening procedure was based on chemical analyses performed in the period 1995-2005 for the city councils and by the Regional Environmental Agency. In total 279 wells were included in the present study, of which 110 are municipal wells for public supply and the remaining are private wells, drilled mostly for irrigation and domestic use. The latter cannot be selected for public supply, but were included to provide a regionally more comprehensive overview of groundwater quality in the Algarve.

Based on all the available analyses, a standard violation index (SVI) was calculated for each well, for different sets of variables, based on the associated drinking water standards, represented by the parametric values (PVs) of the EU Drinking Water Directive (98/83/CE). Such water quality indices (WQIs) have been developed with the aim of rapidly combining a large quantity of chemical information of a water sample into a single value and thereby easily monitor spatial and temporal fluctuations of water quality (e.g. Harkins, 1974; Backman et al., 1998; Stigter et al., 2006b). For a given period $t_{0}-t_{u}$, where $t_{0}$ and $t_{u}$ are the initial and final dates of the considered analyses, the SVI is calculated in the following way:

$\mathrm{SVI}_{\mathrm{vars}, i}=\frac{\mathrm{NV}_{\text {vars }, i}}{\mathrm{NA}_{\text {vars }, i}}$

where, $\mathrm{SVI}_{\mathrm{vars}, i}$ is the standard violation index of the variable set "vars" in well $i, \mathrm{NA}_{\mathrm{vars}, i}$ the number of analyses and
$\mathrm{NV}_{\text {vars, } i}$ the number of drinking water standard violations. The created SVIs, shown in Table 2, vary between 0 and 1 ( $100 \%$ of violations).

$\mathrm{SVI}_{\text {Tox }}$ is based on toxic substances. Any violation revealed by this index results in the exclusion of the corresponding well for drinking water purposes and requires further attention. $\mathrm{SVI}_{\text {Microb }}$ is an indicator of microbiological contamination and the level of disinfection required during water treatment. As this type of groundwater contamination is frequent, it is useful to classify the water samples among the water treatment categories A1, A2, A3 defined by Council Directive 75/440/EEC (for surface water, but also applicable to groundwater). $\mathrm{SVI}_{\mathrm{NO}_{3}, \mathrm{Cl}}$ combines two parameters that are typical indicators of a disturbance of the natural state of groundwater, often due to human activities. For instance, agricultural practices have a large impact on concentrations of both parameters in the region, due to excess fertilization and groundwater extraction for irrigation (e.g. Stigter et al., 2006a, b). Neither nitrate nor chloride are removed from water in conventional treatment plants, hence violations of drinking standards impair the use of the well for this purpose, though groundwater may be mixed with surface water to obtain acceptable levels. $\mathrm{SVI}_{\mathrm{Fe}, \mathrm{Mn}}$ indicates the need of iron and manganese removal from groundwater for public supply, increasing the treatment costs. Both parameters are treated at water treatment plants, though they can form stable complexes with humic substances and become more resistant to oxidation.

For the screening and selection procedure, the wells were distributed among six quality classes. Class 1 represents the highest quality and includes wells extracting groundwater that after a basic disinfection are ready to be used for drinking water purposes. The selection criteria for the first class were defined as follows:

1. all samples of the well in class $\mathrm{A} 1$ of required microbiological treatment (75/440/EEC);

2. $\mathrm{SVI}_{\mathrm{Fe}, \mathrm{Mn}} \leq 0.25$ (maximum one violation in four analyses);

3. $\mathrm{SVI}_{\mathrm{Tox}}=0$ and $\mathrm{SVI}_{\mathrm{NO}_{3}, \mathrm{Cl}}=0$ (no violations permitted). 

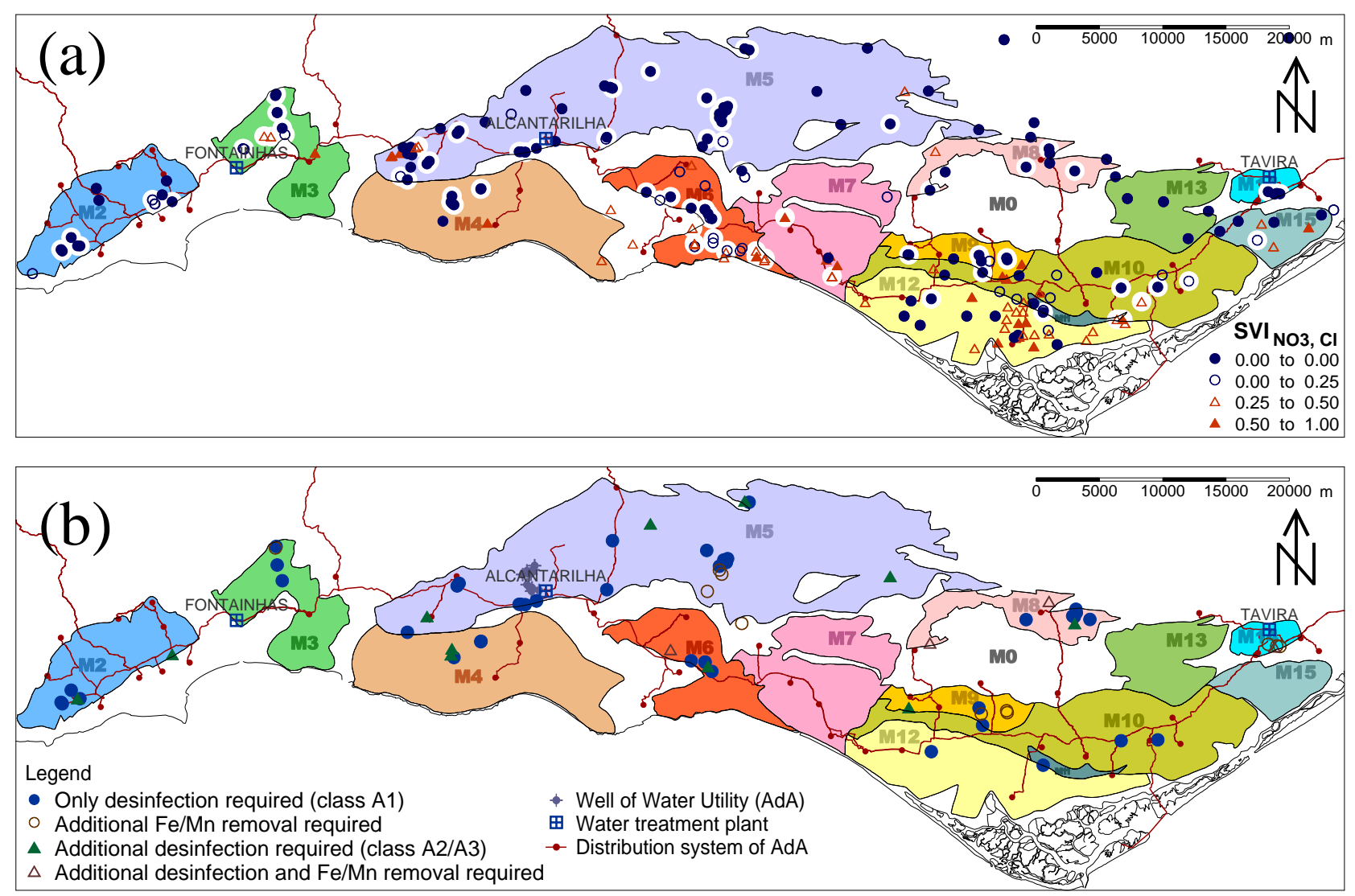

Fig. 3. (top) Spatial distribution of SVINO3,Cl for municipal wells (white background) and private wells in the main aquifer systems of the Algarve; Fig. 3b (bottom) Location of municipal wells selected by screening procedure, indicating different treatment requirements; also shown in the distribution system of the Water Utility.

The reason of loosening the $\mathrm{SVI}_{\mathrm{Fe}, \mathrm{Mn}}$ criterion is twofold. First, elevated concentrations in groundwater are caused by natural rather than human factors. Second, concentrations of iron and manganese are reduced during water treatment. Based on the same reasoning, the hypothesis of loosening the criterion for $\mathrm{SVI}_{\mathrm{NO}_{3}, \mathrm{Cl}}$ was rejected: high concentrations of $\mathrm{NO}_{3}$ and $\mathrm{Cl}$ are due to human impact in the majority of cases, whereas their removal during water treatment does not occur.

Wells of class 2 and 3 only require additional iron and manganese removal $\left(\mathrm{SVI}_{\mathrm{Fe}, \mathrm{Mn}}>0.25\right)$ and disinfection (class A2 and A3), respectively, whereas wells of class 4 require both. Hence, wells of classes 2, 3 and 4 can all be used in the MPWSS as long as extracted groundwater is previously diverted to water treatment plants or receives the required treatment in situ. The last two classes include wells that are not considered for drinking water, either due to the presence of nitrate and chloride (class 5) or toxic substances (class 0).

\subsection{Results and discussion}

Of the referred parameters, it is widely recognized that microbiological contamination can have serious consequences for public health. Nitrate in drinking water is generally considered to constitute a health hazard for babies and young infants. Its toxicity is mainly attributable to the reduction to nitrite and associated to methaemoglobinemia, although several recent studies question this fact (e.g. L'hirondel and L'hirondel, 2002; Addiscott, 2006). As far as known, no health problems are related to iron and manganese for humans, but their presence in public water supplies can create serious problems. In distribution systems, they can cause difficulties by supporting the growth of iron bacteria and impart a taste to water (for iron) detectable at very low concentrations (Sawyer et al., 2003).

The spatial distribution of one of the standard violation indexes, $\mathrm{SVI}_{\mathrm{NO}_{3}, \mathrm{Cl}}$, in the main aquifer systems of the Algarve is shown in Fig. 3a. Since only municipal wells with zero index values are considered for integration into the MPWSS, the map already provides a good overview of the aquifer systems that are most interesting from a qualitative point of 

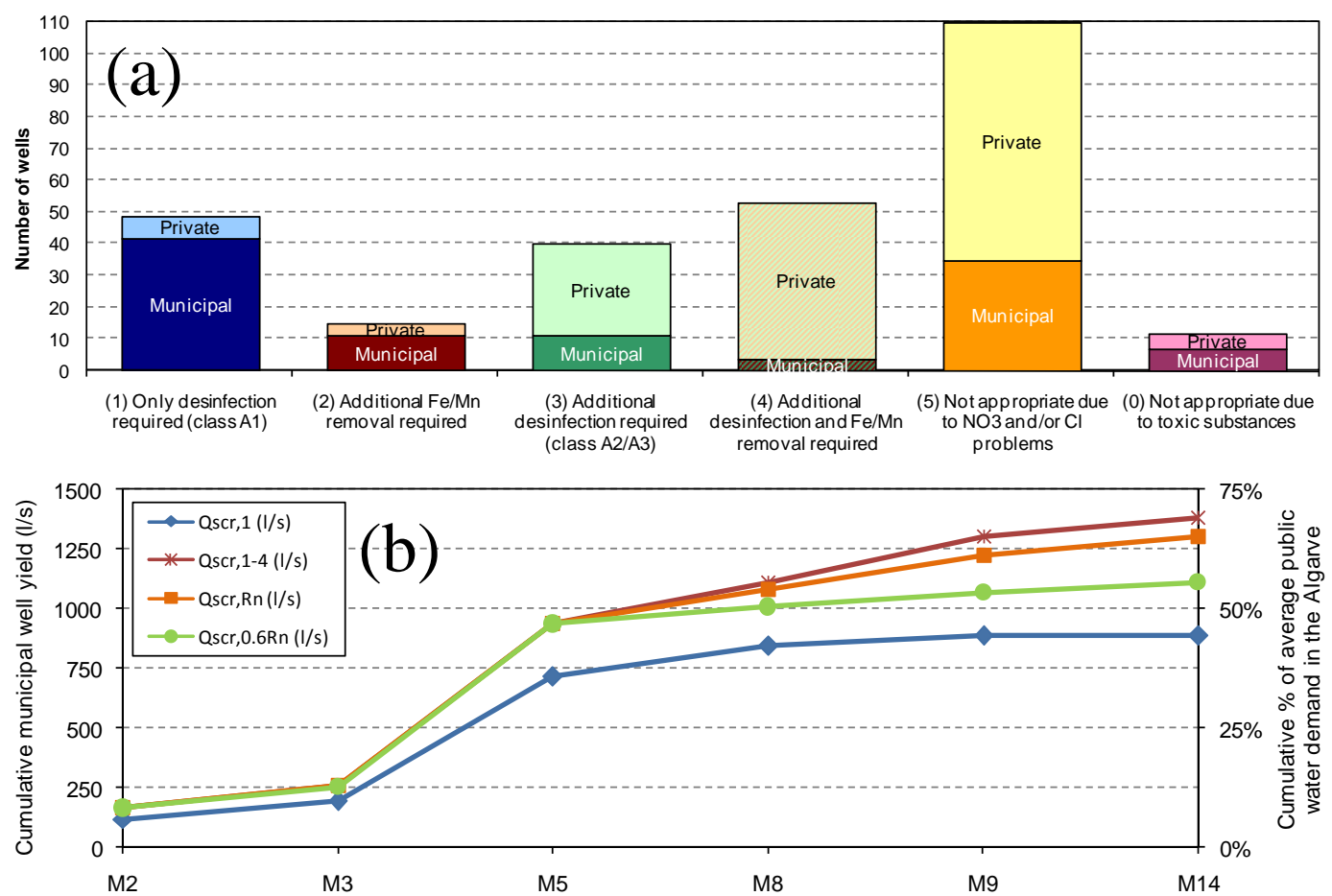

Fig. 4. (top) Results of SVI calculations and application of selection criteria for each treatment class; Fig. 4b (bottom) Absolute and relative values of cumulative well yield for the main aquifer systems; relative values are based on continuous pumping and compared to the average public water demand in the region. Qscr,1 = installed yield from selected municipal wells of class 1 of the screening procedure; Qscr,1-4 = installed yield from selected municipal wells of class 1-4 of the screening procedure; Qscr, $R_{n}=$ maximum available yield from municipal wells so that total withdrawals do not exceed $100 \%$ of natural recharge $\left(R_{n}\right)$, Qscr, $0.6 R_{n}=$ maximum available yield from municipal wells so that total withdrawals do not exceed $60 \%$ of $R_{n}$.

view. The highest index scores (worst water quality) are observed in the coastal aquifer systems M6, M12 and M15, either due to saltwater intrusion caused by groundwater extractions (M6) or related to agricultural contamination (M12 and M15), which has led to the designation of two vulnerable zones in compliance with the Nitrates Directive 91/676/EEC (Stigter et al., 2006b).

The lowest $\mathrm{SVI}_{\mathrm{NO}_{3}, \mathrm{Cl}}$ scores (best water quality) are found in aquifer systems M2 (western sector), M3 (northern sector), M5 (except for its westernmost sector, near the Arade estuary), M8, M9 and M14. These are carbonate aquifers, with high recharge rates and groundwater velocities, and often located more inland, protected from seawater intrusion. Their dominant role for public water supply is manifested in the map of Fig. 3b, which locates the wells selected for integration into the MPWSS, as a result of the screening procedure.

Figure $4 \mathrm{a}$ shows the distribution of the selected wells distributed among the six treatment classes, according to the selection criteria. Over 60 municipal wells can be integrated into the MPWSS, of which 42 belong to class 1, i.e. only require disinfection prior to their use for drinking water. The presence of toxic substances (i.e. lead, arsenic, nickel, mercury and pesticides) was only detected in 15 of the 5670 analyses and related to local accidental spills, without any long-term consequences. In fact, three municipal wells with a $\mathrm{SVI}_{\text {Tox }}>0$ and therefore not considered for public supply in this study, are currently still operational, located in the largest aquifer system (M5) and with a total well yield of $1111 \mathrm{~s}^{-1}$.

Figure $4 \mathrm{~b}$ presents the cumulative yield from municipal wells for the six main aquifer systems. Although several other aquifer systems contain wells that passed the screening process, it was decided to leave them out of the calculations, due to generally lower aquifer productivity (M4, M10) or problems with water quality in wells located nearby in the same aquifer (M6, M12). It can be observed that almost $9001 \mathrm{~s}^{-1}$ can be obtained from groundwater after disinfection, whereas an additional $4001 \mathrm{~s}^{-1}$ can be included after iron and manganese removal and additional disinfection. These numbers are based on maximum installed pumping capacity and continuous pumping and are of little use for water supply management, because they do not consider the limiting factors for groundwater availability, i.e. natural recharge, the presence of other water consumers (mainly agriculture) and ecological demands. The next section will deal with the sustainability of groundwater withdrawals from the selected wells. 
Table 3. Relation between available municipal well yields and mean annual recharge.

\begin{tabular}{llrrrrr}
\hline Code & Name & $\begin{array}{r}Q_{\mathrm{scr}}^{\mathrm{a}} \\
\left(\mathrm{hm}^{3} \mathrm{yr}^{-1}\right)\end{array}$ & $\begin{array}{r}Q_{\mathrm{agr}}^{\mathrm{b}} \\
\left(\mathrm{hm}^{3} \mathrm{yr}^{-1}\right)\end{array}$ & $\begin{array}{r}Q_{\mathrm{tot}}^{\mathrm{c}} \\
\left(\% R_{n}\right)\end{array}$ & $\begin{array}{r}Q_{\mathrm{scr}, R_{n}}^{\mathrm{d}} \\
\left(\mathrm{hm}^{3} \mathrm{yr}^{-1}\right)\end{array}$ & $\begin{array}{r}Q_{\mathrm{scr}, 0.6 R_{n}}^{\mathrm{e}} \\
\left(\mathrm{hm}^{3} \mathrm{yr}^{-1}\right)\end{array}$ \\
\hline M2 & Almádena - Odeáxere & 5.2 & 2.6 & $47 \%$ & 5.2 & 5.2 \\
M3 & Mexilhoeira Grande - Portimão & 2.9 & 2.0 & $61 \%$ & 2.9 & 2.8 \\
M5 & Querença - Silves & 21.5 & 31.0 & $56 \%$ & 21.5 & 21.5 \\
M8 & S. Brás de Alportel & 5.5 & 1.0 & $117 \%$ & 4.5 & 2.3 \\
M9 & Almansil - Medronhal & 6.0 & 2.0 & $123 \%$ & 4.5 & 1.9 \\
M14 & Malhão & 2.5 & 0.5 & $98 \%$ & 2.5 & 1.3 \\
Total & & 43.6 & 42.1 & & 41.1 & 35.0 \\
\hline
\end{tabular}

\footnotetext{
a installed yield from selected municipal wells based on screening procedure

$\mathrm{b}$ groundwater consumption rate of agriculture

${ }^{\text {c }} Q_{\text {scr }}+Q_{\text {agr }}$, as $\%$ of mean annual recharge $R_{n}$

d maximum available yield from municipal wells so that $Q_{\text {tot }}$ does not exceed $100 \%$ of $R_{n}$

${ }^{\mathrm{e}}$ maximum available yield from municipal wells so that $Q_{\text {tot }}$ does not exceed $60 \%$ of $R_{n}$
}

\section{Sustainability assessment of public water supply from selected wells}

Safe yield is defined by Sophocleous (1997) as the attainment and maintenance of a long-term balance between the amount of groundwater withdrawn annually and the annual amount of recharge. Currently, the emphasis has shifted to sustainable yield (Sophocleous, 2000; Custodio, 2002; Alley and Leake, 2004; Maimone, 2004; Kalf and Woolley, 2005; Seward et al., 2006; Ponce, 2007), which reserves a fraction of safe yield for ecological demands. This need was already recognized a long time ago by Lee (1915) and Theis (1940), but no general rule exists as to what percentage of recharge can be considered sustainable. The latter depends on many regional factors, such as climate (and climate change), hydrogeological setting, the particular location of the wells and the presence of groundwater dependent ecosystems.

Table 3 and Fig. 4b present a first impression of the relation between the screened installed yield from municipal wells and the mean annual recharge $\left(R_{n}\right)$. Two scenarios of maximum abstraction rates are considered here: $100 \%$ and $60 \%$ of $R_{n}$. Hence, only the latter scenario accounts for a long-term groundwater discharge component (ecological demand), but can also be seen to reflect reduced recharge caused by climate change. Climate models predict a maximum $40 \%$ lowering of precipitation by 2100 in the south of Portugal (Santos and Miranda, 2006). In order to assess available groundwater volumes for public supply, other water consumers need to be included, which is done for agriculture, by far the most significant consumer in the region (see Table 3).

The curves in Fig. $4 \mathrm{~b}$ allow a rapid perception of the available well yields requiring disinfection (class 1) or further treatment (class 2-4) and those yields limited by the imposed criteria of sustainability. The four curves are only distinguishable for the smaller aquifer systems M8, M9 and
M14, clearly indicating that abstraction rates are limited here by natural recharge. In the safest scenario, i.e. that of $40 \%$ groundwater discharge, maximum available well yields are between $30 \%$ and $50 \%$ of installed yield, and even in the "no discharge" scenario maximum yields are $75 \%$ and $82 \%$ of installed yield for M9 and M8, respectively.

Nevertheless, their contribution can be significant. For instance, groundwater of aquifer system M14 and the northern sector of aquifer system M3 can be diverted to the nearby located treatment plants, where they can be mixed with surface water prior to treatment. The typical natural characteristics of groundwater, such as high degree of hardness and low turbidity, make it extremely advantageous for mixing with surface water, with regard to treatment requirements (e.g. Campinas et al., 2001). In order to assess water quality changes driven by mixing hydrochemical models are being applied.

Even when considering that $40 \%$ of $R_{n}$ is unavailable (due to a combination of reduced recharge and ecological requirements), the total available yield from municipal wells is $35 \mathrm{hm}^{3}$ (Table 3), more than $1100 \mathrm{l} \mathrm{s}^{-1}$ or $55 \%$ of the regional water demand in the Algarve (Fig. 4b). With an installed well yield of $21.5 \mathrm{hm}^{3}$ based on the screening procedure, the aquifer system of Querença-Silves (M5) is by far the largest public groundwater provider. Studying its response to such large withdrawal rates is therefore a critical task, which can be supported by a groundwater flow simulation model. Such a model can simulate groundwater flow under natural conditions and subsequently incorporate pumping activities from the screened wells, as well as from private irrigation wells, so that the risk of overexploitation can be comprehensively assessed for different scenarios. Overexploitation in aquifer system M5 could lead to the drying up of springs and associated wetlands, as well as aquifer degradation due to seawater intrusion. 


\subsection{Groundwater flow model of the Querença-Silves aquifer system}

\subsubsection{Methods}

The first step towards synthesizing the Querença-Silves aquifer system at the regional scale using a numerical model involved the transformation of the available hydrogeological information into a general conceptual flow model, considering: (1) the geometry of the aquifer system, (2) the boundary conditions and location of the main discharge areas and (3) the recharge and discharge rates (Monteiro et al., 2006, 2007b). The geometry of the aquifer system is pictured in Fig. 2 and discussed in Sect. 2.2. Boundary conditions were defined as constant head along the Arade estuary in the west and no-flow for the remaining part. Since there is strong tidal influence in the estuary, it would be more accurate to define a specified (non-constant) head boundary condition, which will be tested in future model runs. Boundary conditions could have been defined for several small springs in the central and eastern sector, but model variants based on these conditions revealed a minor impact on the regional flow pattern and water balance.

Annual recharge rates, depicted in Fig. 2, were determined as the fraction of deep infiltration of the precipitation, considering: (i) the Kessler method (1965) in areas of carbonate rock outcrops and (ii) the semi-empirical formulae of Coutagne (1954), Turc (1954) and Thornthwaite (1948), the latter combined with transient soil water balance/storage models, to calculate real evapotranspiration in areas of sedimentary deposits. During the implementation of regional flow models in the Algarve, the accuracy of these recharge estimates, first performed in the 1980s (Almeida, 1985) was improved, due to: i) the improved accuracy of the geometric representation of the lithological outcrops, based on more recent available information of geologic maps; ii) the improved accuracy and spatial resolution of rainfall, through the implementation of advanced methods, namely kriging with external drift on an orthogonal grid with a resolution of $1 \mathrm{~km}^{2}$, with elevation proving to be the most representative auxiliary variable (Nicolau, 2002). The new recharge estimates were validated with the FAO dual crop coefficient method (Allen et al., 1998), taking into account parameters such as daily precipitation, soil texture, moisture content and vegetation cover (Monteiro et al., 2007a; Mendes Oliveira et al., 2008) and resulting in a 3\% higher estimated recharge.

The defined conceptual flow model was translated to a finite element mesh with 11663 nodes and 22409 triangular finite elements. The physical principles at the basis of the simulation of the hydraulic behavior of the aquifer system are expressed by:

$$
S \frac{\partial h}{\partial t}+\operatorname{div}(-[T] \overrightarrow{\operatorname{grad}} h)=Q
$$

where: $T$ is transmissivity $\left[L^{2} T^{-1}\right], h$ is the hydraulic head $[L], Q$ is a volumetric flux per unit volume $\left[L^{3} T^{-1} L^{-3}\right]$, representing sources and/or sinks and $S$ is the storage coefficient [-]. For the first simulations steady-state conditions were used, where the variables are time-independent, so that Eq. (1) is reduced to:

$\operatorname{div}(-[T] \overrightarrow{\operatorname{grad}} h)=Q$

The representation of the flow domain of karst systems as single continuum equivalent porous media, using the concepts of hydraulic conductivity $(K)$ and its bidimensional derivative $T$, is valid when modelling hydraulic heads and flow volumetrics on a regional scale, as is discussed by Scanlon et al. (2003).

The direct solution was implemented using a standard finite-element model based on the Galerkin method of weighted residuals, implemented in FEFLOW (Koskinen et al., 1996). Preliminary results showed that the hydraulic parameters obtained from pumping tests allowed the analysis of coherence between existing conceptual flow models and the observed regional flow patterns, but were not adequate to obtain realistic simulations of the spatial distribution of hydraulic head in several sectors. Therefore, $T$ was estimated by inverse modelling. In the current analysis, three scenarios were created:

SCENARIO 1: steady-state flow under natural conditions, i.e. no pumping. This scenario was based on the highest observed water levels in the past 20 years and used for inverse calibration of $T$, using the Gauss-MarquardtLevenberg method, implemented in the nonlinear parameter estimation software PEST (Doherty, 2002). Although based on an automated procedure, calibration was not straightforward and involved a dozen of different zonation schemes before reaching the final configuration with $23 \mathrm{~T}$ zones presented in Fig. 5. Within each zone the behaviour of piezometers allowed a reasonable fitting of field data using a single value of $T$. This configuration corresponds to an accurate representation of the actual knowledge of the aquifer regarding its hydraulic behaviour in both natural conditions and in response to extractions in wells.

The $T$ values obtained from calibration are always higher than the maximum individual values of this parameter calculated from pumping tests in each zone, as $T$ results from the multiplication of aquifer thickness by $K$, a parameter whose value tends to increase with scale (Király, 1978; Sauter, 1992). This important additional constraint for calibration was defined to avoid unrealistic conceptualisations of the flow domain, i.e. unrealistic $T$ values despite a good fit between observed and calculated heads. In the latter case the model would probably present very poor results in stress conditions different from the ones used in calibration (for example in drought conditions). These imposed limits of parameter-value acceptability are considered as "soft data" that cannot be directly incorporated into the model, but can 


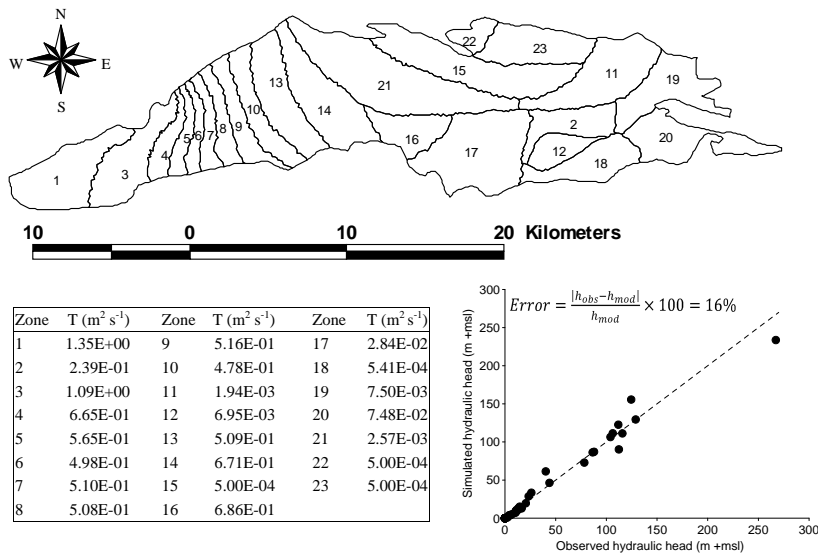

Fig. 5. Map with established zonation for estimation of transmissivity (top), optimized values obtained by inverse calibration (bottom left) and resulting plot of modelled versus observed hydraulic heads (bottom right).

be of great importance to improve model quality. For example, regarding the most transmissive area of the aquifer (western sector), $T$ values determined from pumping tests reach values as high as $30000 \mathrm{~m}^{2} \mathrm{~d}^{-1}\left(0.347 \mathrm{~m}^{2} \mathrm{~s}^{-1}\right)$, often determined in wells supporting yields of over $1001 \mathrm{~s}^{-1}$ and attaining maximum depths of $400 \mathrm{~m}$. However, the thickness of the carbonate formations supporting the aquifer system in the south is in the order of $600 \mathrm{~m}$ or more. A realistic representation of the aquifer at the regional scale in this sector is based on zones with $T$ values higher than $1 \mathrm{~m}^{2} \mathrm{~s}^{-1}$ (see Fig. 5).

SCENARIO 2: activating the groundwater pumping wells in a steady-state model (scenario 2a) and transient model (scenario 2b). Public water supply was distributed among extraction wells with known location and pumping rates, using the highest observed annual withdrawals in the steady-state model: $21.5 \mathrm{hm}^{3}$ in the hydrological year of $2004 / 2005$. The latter volume (coincidentally) corresponds to the installed annual yield from selected municipal wells based on screening procedure (Table 3 ). For irrigation an annual withdrawal of $31 \mathrm{hm}^{3}$ was considered (Nunes et al., 2006b), distributed over 150 irrigation wells inserted into the model (located within the irrigated areas of Fig. 2). Transient simulations were performed from January 2003 to April 2006, therefore including the drought period of 2004-2005. In this case irrigation wells were only activated from May to September of each year. Regarding the storage coefficient $S$, many trials were performed with alternative values. Many of the runs provided relatively pessimistic scenarios when compared to observed data, simulating the inversion of the hydraulic gradient and consequent seawater intrusion from the Arade estuary in some periods, which could not be performed in practice. A final $S$ of 0.05 was used, which provided reliable simulations for the entire period, including the long-lasting drought in 2005 . This value was subsequently validated with observed hydraulic head time series in several monitoring wells and observed spring discharges at the Arade estuary, showing consistency with calibration results. For a fissured limestone matrix, the resulting $S$ may be considered as high, but not uncommon; moreover, the value is theoretically consistent, as discussed by Monteiro (2001) and Reimann et al. (2008).

SCENARIO 3: reducing natural groundwater recharge in the steady-state model by $40 \%$, based on the predicted decrease in rainfall by 2100 (Santos and Miranda, 2006), while maintaining the groundwater withdrawal volumes for public supply and irrigation. Using a value of $40 \%$ may be considered somewhat arbitrary, as the real scenario may be less drastic (precaution principle). Groundwater recharge is expected to further decrease due to higher evapotranspiration rates caused by increasing temperatures. A minor difference with the previous steady-state model is that besides the Water Utility wells only the screened wells are used, rather than the wells where groundwater withdrawal actually occurred in the years 2005/2006. As it was decided to maintain a constant public supply of $21.5 \mathrm{hm}^{3}$, including screened and Water Utility wells, pumping rates were set at $66 \%$ of maximum rates. Naturally, this is a simplification of the reality, as it is difficult to predict if and how change in climate and water consumption will lead to a new steady-state situation. More accurate simulations can be provided by transient scenario modelling if climate change data are available with sufficient temporal resolution, which is currently being studied. The idea here is to study the impact of strong (40\%) decline in recharge, or a less significant decrease combined with an increase in water consumption by economic sectors.

\subsubsection{Results and discussion}

Regarding scenario 1, the modelled equipotential map in Fig. 6 reveals a steep hydraulic gradient in the NE, where groundwater flow is towards the south. In the western sector the hydraulic gradient is very small and E-W flow direction prevails. The complex flow pattern in the NE is related to the presence of sectors where local karstic structures have a poor hydraulic connection with the main discharge area of the aquifer. Such areas can be characterised as "systematic positive regional anomalies of hydraulic head". Their representation as "low $T$ zones" (Fig. 5) is an assumed simplification of the flow domain that derives from its representation as a single continuum equivalent porous media, which does not interfere with a correct and detailed regional analysis of the hydraulic heads and the water balance. Equivalent porous media models have been successfully applied to karst aquifers by other authors (e.g. Scanlon et al., 2003), the main limitation being that they cannot accurately simulate local scale directions or rates of water flow in the aquifer. If the latter is required, more sophisticated analytical or numerical representations of the flow domain should be used, considering 


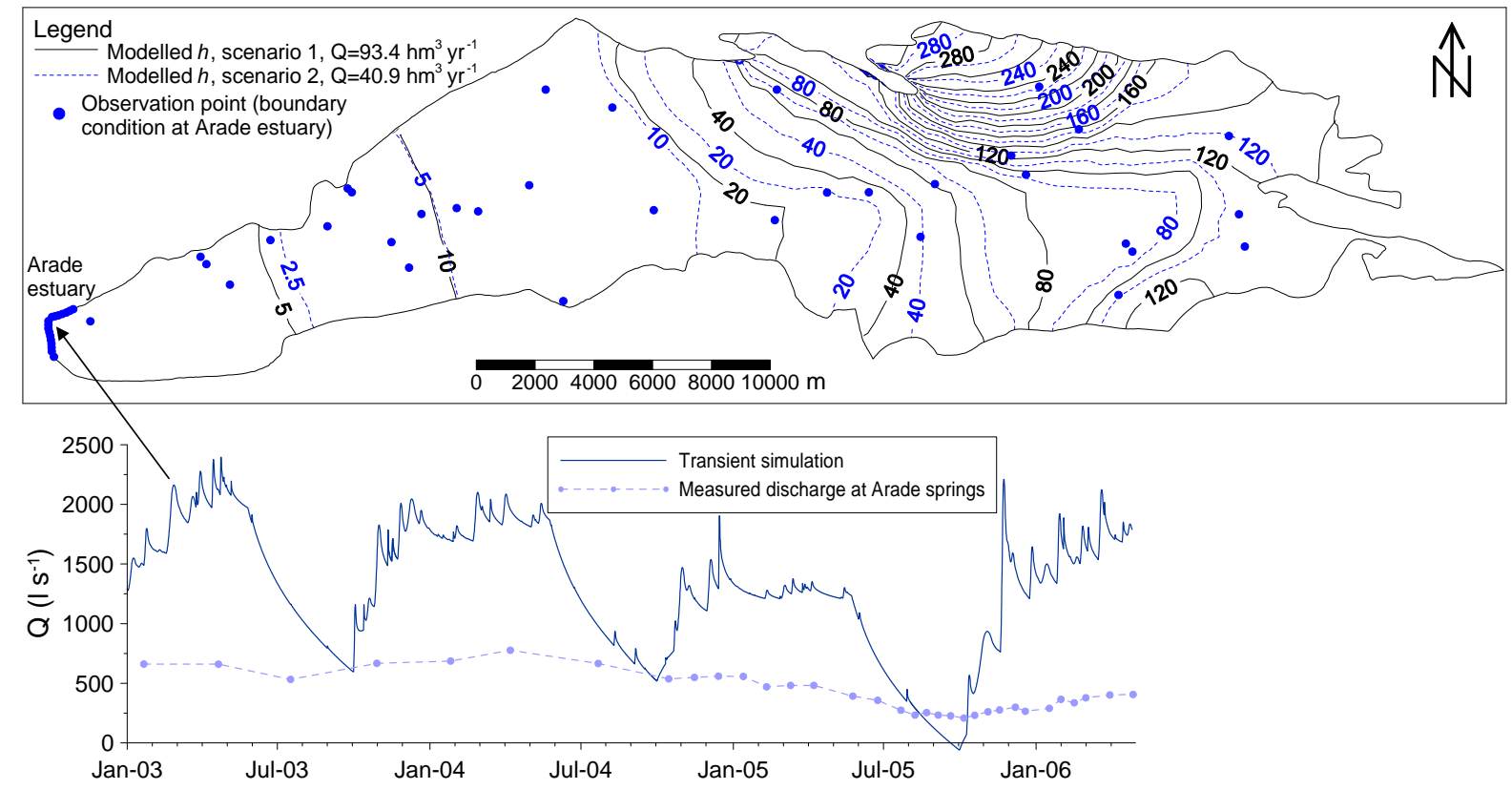

Fig. 6. (top) Spatial distribution maps of simulated hydraulic heads under steady-state conditions, with and without groundwater pumping (scenarios 1 and 2 respectively); (bottom) hydrograph of simulated transferences between the aquifer system and the Arade estuary using daily values of recharge for a period between 1 January 2003 and 24 April 2006.

the presence of discrete conduits or fractures (Monteiro and Ribeiro, 2002; Monteiro and Achour, 2005).

Activating the wells in the steady-state model (scenario 2a) results in a lowering of the hydraulic heads in the central and western sector (Fig. 6), where most waterconsuming activities are concentrated (see Fig. 2). Despite this fact, mean annual recharge is high enough to avoid regional overexploitation on an average yearly basis, as indicated by the positive aquifer water balance (mean outflow $Q$ of $40.9 \mathrm{hm}^{3} \mathrm{yr}^{-1}$ ). For the transient simulation (2b), Fig. 6 presents a hydrograph of the transferences between the aquifer system and the Arade estuary, where positive values represent outflow from the aquifer. Total measured discharge at several springs is also indicated. It can be observed that every year outflow is high during the rainy season and drops significantly during the months of May to September, triggered by the pumping activities, particularly those from irrigation wells, which only pump during these four months, when recharge is also insignificant. Over the entire period, observed outflow is only $40 \%$ of simulated outflow, which is due to the fact that they are local scale features of a regional aquifer - river transference system, excluding submarine (subestuarine) discharge. At the end of the drought period (September 2005), the model simulates a very small and short-lasting gradient inversion, when water from the Arade estuary enters the aquifer. Field observations indicate that freshwater discharge continues to occur, indicating that the transient model requires further adjustment. However, gradient inversions at the springs do occur on a diurnal basis in

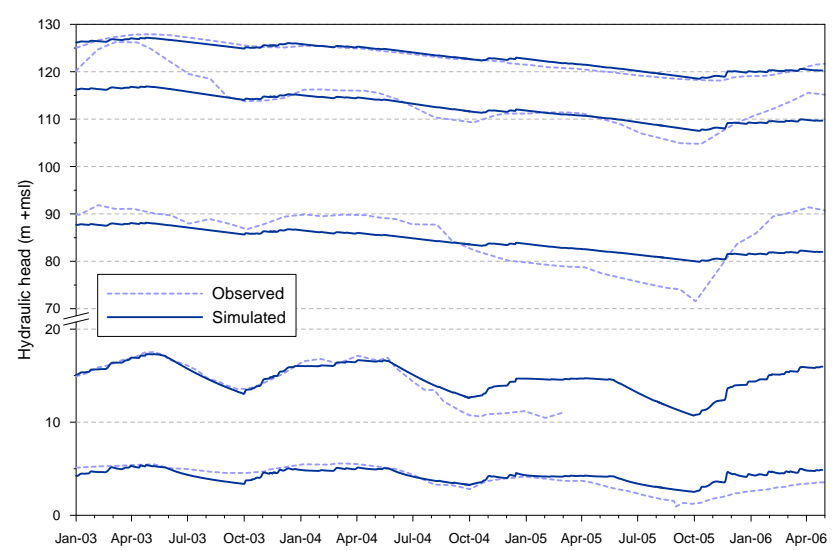

Fig. 7. Modelled oscillations vs. observed time series of hydraulic head for five monitoring wells, during the period of the transient simulation.

response to tidal fluctuations: the input of saltwater in the aquifer is followed by water output with decreasing salinity, due to groundwater discharge, until the next rise of the tide. Therefore, field data need to be corrected for estuarine water salinity.

Figure 7 indicates that modelled hydraulic head variations during the transient simulation closely follow observed time series, though fluctuations appear to be more pronounced at some locations. The latter is probably explained by the use of a constant $S$, which in reality varies spatially. Future work 


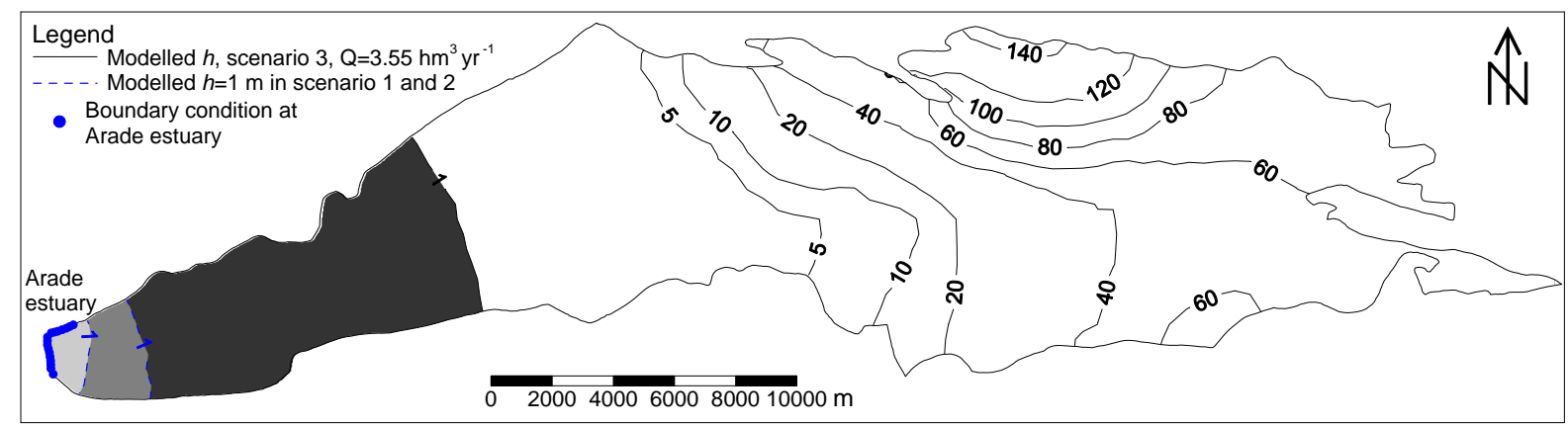

Fig. 8. Simulated impact of a $40 \%$ reduction of mean annual recharge on spatial distribution of hydraulic heads under steady-state conditions with groundwater abstractions (scenario 3); the shaded areas indicate the increase of the area with hydraulic head $(h)<1 \mathrm{~m}$, from scenario 1 (light) to 3 (dark).

should therefore include an analysis of the spatial distribution of this parameter in the aquifer.

The steady-state simulation of reduction in effective recharge (scenario 3) is shown in Fig. 8. Hydraulic heads drop significantly in the entire area, up to $50 \%(120 \mathrm{~m})$ in the northeast and $90 \%$ in the west, where the hydraulic gradient is extremely small. No indications of seawater intrusion are predicted, since the regional mean annual water budget continues to be positive, though reduced to only $6 \%$ $\left(3.5 \mathrm{~m}^{3} \mathrm{yr}^{-1}\right)$ of natural recharge. A simultaneous small increase in groundwater extractions could lead to a negative water budget. It would be extremely difficult to meet ecological demands for the groundwater dependent ecosystems, as the lowering of hydraulic heads would significantly reduce or stop spring discharge. In addition, there would be a need for deeper wells with potentially lower available water volumes due to lower storage capacities. As the steady-state simulation represents an average for long-term situations, the risk of gradient inversion for shorter periods during the dry season or during longer-lasting droughts would largely increase. This is further illustrated by the evolution of the shaded areas, with (steady-state) hydraulic head $(h)$ below $1 \mathrm{~m}$, along the three scenarios in Fig. 8. Whereas from scenario 1 to 2, this area only increases slightly, in scenario 3 the area extends as far as $14 \mathrm{~km}$ inward. Here, negative heads and gradient inversions are likely to occur during summer months and almost certainly during dry years. The spatial and temporal extent to which these gradient inversions cause seawater intrusion and subsequent water impairment for human consumption or irrigation requires further evaluation with the aid of predictive transient model simulations, currently under study.

\section{Conclusions}

Groundwater constitutes an important alternative source for an IWRM in the Algarve region, due to its overall high quality and availability. The application of quantitative and qualitative well screening criteria resulted in the selection of six aquifer systems that can be exploited for public water supply. Some have a modest contribution in terms of water volume, but they can be particularly relevant for water treatment, due to their natural characteristics, i.e. high degree of hardness and low turbidity. In total more than $10001 \mathrm{~s}^{-1}$, around $50 \%$ of the regional water demand, can be used for the MPWSS, after appropriate disinfection and iron and manganese removal.

The standard violation indices (SVIs) have proven to be useful tools for the spatial monitoring of groundwater quality and potability. Their application is simple and based on drinking water guidelines, so that their interpretation is unbiased. Aggregation also implies a loss of information, and trends of decreasing groundwater quality may be hidden if parametric values have not yet been exceeded. Moreover, the SVIs used in the present study all concern parameters that are simultaneously indicative for groundwater chemistry and drinking water quality, so that the selection criteria are only valid for this water source.

Due to its large area and significant recharge, aquifer system M5, known as Querença-Silves, constitutes the most important groundwater reservoir. Despite its significant exploitation, with $40-50 \mathrm{hm}^{3} \mathrm{yr}^{-1}$ for irrigation and public water supply, no negative consequences have been observed so far, concerning seawater intrusion or ecological degradation. The results obtained by inverse calibration of the regional finite element flow model allowed a significant improvement of the simulation reliability of the observed regional flow pattern, owing to a more accurate characterization of the hydraulic head spatial distribution.

Transient simulations clearly demonstrate the impact of recharge episodes and groundwater extractions on aquifer discharge and the risk of water quality and ecological degradation. The inclusion of oscillatory boundary conditions in the model, incorporating the tidal effect, as well as the spatial analysis of the storage coefficient to reflect its heterogeneity in the aquifer system, are subject to further study, as these particular conditions are related with the understanding of the risks of saltwater intrusion. 
Results obtained from predictive modelling point out the need to prepare social and technical tools to alleviate the combined impact from future climate changes and water demand increases in the region. These results are important for water resource planning, even though they should be treated prudently, as they are based on a simplified steady-state scenario. If climate scenarios for effective water recharge at the end of the century are correct, and if no action is taken in the meantime, salinization of groundwater and destruction of ecosystems seem inevitable. Future allocations of water among users will necessarily have to be balanced between socio-economic development and the preservation of natural assets. These are questions that involve inter-generational transference of utilities and require broader definitions of sustainability than those relying essentially on the physical equilibrium of the environment. The present article does not study these matters, but may contribute to helping society, stakeholders and decision makers decide as to the optimal present and future allocation of water resources, based on a more profound understanding of the nature of the problem.

Acknowledgements. The authors wish to acknowledge the Water Utility Águas do Algarve S.A. for funding this work and the FCT - Fundação para a Ciência e a Tecnologia (POCTI/AMB/57432/2004) for supporting the development of the groundwater flow models. The first author holds a post-doctoral research position under the Ciência 2007 program financed by the FCT.

Edited by: N. Romano

\section{References}

Addiscott, T.: Perspective - Is it nitrate that threatens life or the scare about nitrate?, J. Sci. Food Agric., 86, 2005-2009, 2006.

Allen, R. G., Pereira, L. S., Raes, D., and Smith, M.: Crop evapotranspiration - Guidelines for computing crop water requirements, FAO, Irrig. Drain., 56, 300 pp., 1998.

Alley, W. M. and Leake, S. A.: The journey from safe yield to sustainability, Ground Water, 42, 12-16, 2004.

Almeida, C.: Hidrogeologia do Algarve Central, Ph.D., Univ. de Lisboa, Lisbon, 1985.

Almeida, C., Mendonça, J. J. L., Jesus, M. R., and Gomes, A. J.: Sistemas aquíferos de Portugal Continental, Rep. INAG, Lisbon, Portugal, 2000.

Backman, B., Bodiš, D., Lahermo, P., Rapant, S., and Tarvainen, T.: Application of a groundwater contamination index in Finland and Slovakia, Environ. Geol., 36, 55-64, 1998

Booker, J. F., Michelsen, A. M., and Ward, F. A.: Economic impact of alternative policy responses to prolonged and severe drought in the Rio Grande Basin, Water Resour. Res., 41, W02026, doi:10.1029/2004WR003486, 2005.

Burke, S. M., Adams, R. M., and Wallender, W. W.: Water banks and environmental water demands: case of the Klamath Project, Water Resour. Res., 40, W09S02, doi:10.1029/2003wr002832, 2004.
Campinas, M., Lucas, H., and Rosa, M. J.: Tratamento integrado de águas subterrâneas e superficiais na ETA de Alcantarilha, in: Proc. of Encontro Nacional de Entidades Gestoras de Água e Saneamento, 9-11 October 2001, Lisbon, 2001.

Carreira, P. M.: Mecanismos de Salinização dos Aquíferos Costeiros do Algarve, INETI, Lisbon, 1991.

Characklis, G. W., Griffin, R. C., and Bedient, P. B.: Improving the ability of a water market to efficiently manage drought, Water Resour. Res., 35, 823-831, 1999.

Coutagne, A.: Quelques considérations sur le pouvoir évaporant de l'atmosphère, le déficit d'écoulement effectif et le déficit d'écoulement maximum, La Houille Blanche, 360-369, 1954.

Cunha, L. V, Ribeiro, L. T., Oliveira, R. P., and Nascimento, J.: Recursos Hídricos, in: Alterações Climáticas: Cenários, Impactos e medidas de adaptação, Project SIAM2, Santos, F. D. and Miranda, P. (Eds.), Gradiva/F.C.Gulbenkian/FCT/BP, Portugal, 2006.

Custodio, E.: Aquifer overexploitation: what does it mean?, Hydrogeol. J., 10, 254-277, 2002.

Doherty, J.: PEST Model-Independent Parameter Estimation, 4th Ed., Watermark Numerical Computing, Australia, 279 pp., 2002.

Giorgi, F.: Climate change hot-spots, Geophys. Res. Lett., 33, L08707, doi:10.1029/2006GL025734, 2006.

Harkins, R. S.: An objective water quality index, J. Water Pollut. Con. F., 46, 588-591, 1974.

Hidroprojecto and Ambio: Reforço do abastecimento de água ao Algarve - Estudo técnico-económico, Tech. Rep., Lisbon, 2005.

Kalf, F. R. P. and Woolley, D. R.: Applicability and methodology of determining sustainable yield in groundwater systems, Hydrogeol. J., 13, 295-312, 2005.

Kessler, H.: Water balance investigations in the karstic regions of Hungary, in: Proc. AIHS-UNESCO Symposium on Hydrology of Fractured Rocks, Dubrovnik, Croatia, 7-14 October 1965, 91105, 1965.

Király, L.: La notion d'unité hydrogéologique dans le Jura (essai de définition), Ph.D., Univ. de Neuchâtel, Switzerland, 216 pp., 1978.

Koskinen, L., Laitinen, M., Löfman, J., Meling, K., Mészáros, F.: FEFLOW: a finite element code for simulating groundwater flow, heat transfer and solute transport, in: Development and application of computer technique to environmental studies, edited by: Zannetti, V. P. and Brebbia, C.A., Computation Mechanics Publications, Southampton, 287-297, 1996.

Lee, C. H.: The determination of safe yield of underground reservoirs of the closed basin type, T. Am. Soc. Civil Eng., 78, 148$151,1915$.

Letcher, R. A., Jakeman, A. J., and Croke, B. F. W.: Model development for integrated assessment of water allocation options, Water Resour. Res., 40, W05502, doi:10.1029/2003WR002933, 2004.

L'hirondel, J. and L'hirondel, J. -L.: Nitrate and Man. Toxic, Harmless or Beneficial?, CAB Publishing, Wallingford, United Kingdom, 144 pp., 2001.

Loureiro, J. M. and Nunes, M. F.: Monografia hidrológica do Algarve, Direcção Geral dos Recursos e Aproveitamentos Hidráulicos, Lisbon, 1980.

Maimone, M.: Defining and managing sustainable yield, Ground Water, 42, 809-814, 2004.

Mendes Oliveira, M., Oliveira, L., and Lobo Ferreira, J. P.: Estima- 
tiva da recarga natural no Sistema Aquífero de Querença-Silves (Algarve) pela aplicação do modelo BALSEQ_MOD, in: Proc. of 9. ${ }^{\circ}$ Congresso da Água, Cascais, 2-4 April 2008, CD 15 pp., 2008.

Monteiro, J. P. and Achour, F.: Calibration of a Discrete Continuum Flow Model in a Karstic Aquifer, in: Proc. of the Geological Society of America Annual Meeting, Salt Lake City, 16-19 October 2005, GSA Abstracts Vol. 37(7), 34, 2005.

Monteiro, J. P.: Characterisation of a carbonate aquifer for the application of a regional discrete continuum flow model (Castelo de Vide Carbonate Aquifer - Alentejo, Portugal), Ph.D., Univ. de Neuchâtel, Switzerland, 143 pp., 2001.

Monteiro, J. P. and Costa, M. S.: Dams, groundwater modelling and water management at the regional scale in a coastal Mediterranean area (the southern Portugal region - Algarve), Larhyss Journal, 3, 157-169, 2004.

Monteiro, J. P. and Ribeiro, L.: Characterization of a carbonate aquifer for the application of a regional discrete continuum flow model, Acta. Univ. Carol. Geol., 46, 382-386, 2002.

Monteiro, J. P., Vieira, J., Nunes, L., and Younes, F.: Inverse Calibration of a Regional Flow Model for the Querença-Silves Aquifer System (Algarve-Portugal), in: Proc. of the International Congress on Integrated Water Resources Management and Challenges of the Sustainable Development, Marrakech, 23-25 May 2006, p. 44 (CD 6 pp.), 2006.

Monteiro, J. P., Oliveira, M. M., and Costa, J. P.: Impact of the Replacement of Groundwater by dam waters in the AlbufeiraRibeira de Quarteira and Quarteira coastal aquifers, in: Proc. of the XXXV IAH Congress, Groundwater and Ecosystems, Lisbon, 17-21 September 2007, CD 10 pp., 2007a.

Monteiro, J. P., Ribeiro, L., Reis, E., Martins, J., and Matos Silva, J.: Modelling Stream-Groundwater Interactions in the QuerençaSilves Aquifer System, in: Proc. of the XXXV IAH Congress, Groundwater and Ecosystems, Lisbon, 17-21 September 2007, CD 10 pp., $2007 b$.

Mylopoulos, Y. A. and Kolokytha, E. G.: Integrated water management in shared water resources: the EU Water Framework Directive implementation in Greece, Phys. Chem. Earth, 33, 347-353, 2008.

Nicolau, R.: Modelação e mapeamento da distribuição espacial da precipitação - Uma aplicação a Portugal Continental, Ph.D., Univ. Nova de Lisboa, Lisbon, 2002.

Nunes, L., Monteiro, J. P., Cunha, M. C., Vieira, J., Lucas, H., and Ribeiro, L.: The water crisis in southern Portugal: how did we get there and how should we solve it, in: Management of Natural Resources, Sustainable Development and Ecological Hazards, edited by: Brebbia, C. A., Conti, M. E., and Tiezzi, E., T. Ecol. Environ., Vol. 99, WIT Press, 435-444, 2006.

Nunes, G., Monteiro, J. P., and Martins, J.: Quantificação do consumo de água subterrânea na agricultura por métodos indirectos, in: Proc. of IX Encontro de Utilizadores de Informação Geográfica, ESIG, Oeiras, 15-17 November 2006, CD 15 pp., 2006.

Ponce, V. M.: Sustainable yield of ground water, http://ponce.sdsu. edu/groundwater_sustainable_yield.html, 2007.

Postel, S.: Last Oasis: Facing Water Scarcity, Worldwatch Environmental Alert Series, edited by: Starke, L., Norton, W. W. \& Company, Inc, New York, 1992.

Pulido-Velazquez, M., Andreu, J., and Sahuquillo, J.: Economic optimization of conjunctive use of surface and groundwater at the basin scale, J. Water Res. Pl-ASCE., 132, 454-467, 2006.

Pulido-Velazquez, M., Andreu, J., Sahuquillo, J., and PulidoVelazquez, D.: Hydro-economic river basin modelling: the application of a holistic surface-groundwater model to assess opportunity costs of water use in Spain, Ecol. Econ., 66, 51-65, 2008.

Reimann, T., Geyer, T., Dörfliger, N., Birk, S., Jourde, H., Ladouche, B., Liedl, R., and Sauter, M.: Hydraulic characterisation of a karst aquifer using large-scale pumping tests in the conduit system, in: Proc. of the 13th World Water Congress, Montpellier, France, 1-4 September 2008, 9 pp., 2008.

Salgueiro, A. R. and Ribeiro, L.: Assessment of saltwater intrusion risk at Mexilhoeira Grande - Portimão aquifer (Portugal) by indicator geostatistics, in: Proc. of the First International Conference on Salt Water Intrusion and Coastal Aquifers - Monitoring, Modeling and Management, Essaouira, Morocco, 23-25 April 2001, Nr. 68, 2001.

Santos, F. D. and Miranda, P. (Eds.): Alterações climáticas em Portugal. Cenários, Impactos e Medidas de Adaptação - Project SIAM II, Gradiva, Lisbon, Portugal, 2006.

Sauter, M.: Quantification and forecasting of regional groundwater flow and transport in a karst aquifer (Gallusquelle, Malm, SW. Germany), Tübinger Geowissenschaftliche Arbeiten, C13, 150 pp., 1992.

Savenije, H. H. G.: Why water is not an ordinary economic good, or why the girl is special, Phys. Chem. Earth, 27, 741-744, 2002.

Sawyer, C. N., McCarty, P. L., and Parkin, G. F.: Chemistry for environmental engineering and science, 5th Ed., McGraw-Hill, New York, 2003.

Scanlon, B. R., Mace, R. E., Barrett, M. E., and Smith, B.: Can we simulate regional groundwater flow in a karst system using equivalent porous media models? Case study, Barton Springs Edwards aquifer, USA, J. Hydrol., 276, 137-158, 2003.

Seward, P., Xu, Y., and Brendonck., L.,: Sustainable groundwater use, the capture principle, and adaptive management, Water SA, 32(4), 473-482, 2006.

Silva, M. J. B. L.: Hidrogeologia do Miocénico do Algarve, Ph.D., Univ. de Lisboa, 1988.

Silva, M. O.: Hidrogeologia do Algarve Oriental, Ph.D., Univ. de Lisboa, 1984.

Sophocleous, M.: Managing water resources systems: Why "safe yield" is not sustainable, Ground Water, 35, p. 561, 1997.

Sophocleous, M.: From safe yield to sustainable development of water resources - the Kansas experience, J. Hydrol., 235, 27-43, 2000.

Stigter, T. Y., Ooijen, S. P. J., Post, V. E. A., Appelo, C. A. J., and Carvalho Dill, A. M. M.: A hydrogeological and hydrochemical explanation of the groundwater composition under irrigated land in a Mediterranean environment, Algarve, Portugal, J. Hydrol., 208, 262-279, 1998.

Stigter, T. Y., Carvalho Dill, A. M. M., Ribeiro, L., and Reis, E.: Impact of the shift from groundwater to surface water irrigation on aquifer dynamics and hydrochemistry in a semi-arid region in the south of Portugal, Agr. Water Manage. 85, 121-132, 2006 a.

Stigter, T. Y., Ribeiro, L., and Carvalho Dill, A. M. M.: Application of a groundwater quality index as an assessment and communication tool in agro-environmental policies - two Portuguese case studies, J. Hydrol., 327, 578-591, 2006 b.

Stigter, T. Y., Monteiro, J. P., Nunes, L. M., Vieira, J., Cunha, M. C., 
Ribeiro, L., and Lucas, H.: Strategies for integrating alternative groundwater sources into the water supply system of the Algarve, Portugal, in: Proc. of the 2nd IWA Leading Edge Conference on Strategic Asset Management, Lisbon, 17-19 October 2007, p. 144, CD 15 pp., 2007.

Tanaka, S. K., Zhu, T., Lund, J. R., Howitt, R. E., Jenkins, M. W., Pulido-Velazquez, M., Tauber, M., Ritzema, R. S., and Ierreira, C.: Climate warming and water management adaptation for California, Clim. Change, 76, 361-384, 2006.
Theis, C. V.: The source of water derived from wells: Essential factors controlling the response of an aquifer to development, Civil Eng., 10, 277-280, 1940.

Thornthwaite, C. W.: An approach towards a rational classification of climate, Geogr. Rev., 38, 55-94, 1948.

Turc, L.: Le bilan d'eau des sols, relation entre les précipitations, l'évaporation et l'écoulement, Ann. Agron. 5, 491-596, 1954.

Ward, F. A. and Pulido-Velazquez, M.: Efficiency, equity, and sustainability in water quantity-quality optimization model in the Rio Grande basin, Ecol. Econ., 66, 23-37, 2008. 